\section{USVL-220, a Novel Watermelon Breeding Line}

\author{
Amnon Levi ${ }^{1,7}$, Judy A. Thies ${ }^{2}$, Alvin M. Simmons ${ }^{3}$, and \\ Howard Harrison ${ }^{4}$
}

U.S. Department of Agriculture, Agricultural Research Service, U.S. Vegetable

Laboratory, 2700 Savannah Highway, Charleston, SC 29414

\section{Richard Hassell ${ }^{5}$ and Anthony Keinath ${ }^{6}$}

Clemson University, Coastal Research and Education Center, 2700 Savannah Highway, Charleston, SC 29414
USVL-220 is a novel watermelon [Citrullus lanatus (Thunb.) Matsum. \& Nakai] breeding line containing the nuclear genome of watermelon cultivars (Citrullus lanatus var. lanatus) and cytoplasmic background (chloroplast and mitochondrial genomes) decynthis (L.) Schrad. USVL-220 was developed at the USDA, ARS, U.S. Vegetable Laboratory, Charleston, SC.

Development of USVL-220 began in 1999 with the greenhouse observations of $\mathrm{F} 1$ plants derived from reciprocal crosses between the U.S. PI 386015 (C. colocynthis) and the watermelon cultivars New Hampshire Midget (NHM), Extra Early Sugar Baby, Allsweet, or Charleston Gray (C. lanatus var. lanatus). In general, $\mathrm{F} 1$ plants derived from a cross in which the C. colocynthis (PI 386015) was the maternal parent produced a female flower for every two to three male flowers. Conversely, melon cultivar was used as the maternal parent, the F1 plants produced a female flower for every four to six (NHM) or five to seven ('Allsweet' or 'Charleston Gray') male flowers (Levi et al., 2006). Like with most plant species, the chloroplast and mitochondria are inherited maternally in watermelon (Havey et al., 1998; Levi and Thomas, 2005). Several studies have indicated that interaction between nuclear and maternally inherited (chloroplast or mitochondrial) genes affect flower morphogenesis in plant species (Ehlers et al., 2005; Kheyr-Pour, 1980; Ross, 1978; Ross and Gregourius, 1985; Van der Hulst et al., 2004; Wade and McCauley, 2005). Diolez et al. (1986) indicated that mitochondria play a role in the biosynthesis of endogenous ethylene in plant tissues, whereas Salman et al. (2008)

Received for publication 10 May 2010. Accepted for publication 4 Nov. 2010.

Use of trade names does not imply endorsement of the product names nor criticism of similar ones not named.

${ }^{1}$ Research Geneticist.

${ }^{2}$ Research Pathologist.

${ }^{3}$ Research Entomologist.

${ }^{4}$ Research Agronomist.

${ }^{5}$ Horticulturist.

${ }^{6}$ Plant Pathologist.

${ }^{7}$ To whom reprint requests should be addressed; e-mail Amnon.Levi@ARS.USDA.GOV. rived from the desert species Citrullus coloin the reciprocal cross, in which a water- suggested that ethylene reduces the formation of female flowers in watermelon.

A wide genetic diversity exists between watermelon cultivars (C. lanatus var. lanatus) and U.S. PIs of C. lanatus var. citroides and $C$. colocynthis, indicating that a large number of exotic alleles may have been excluded during many years of cultivation and selection for watermelon with desirable fruit qualities (Levi et al., 2001). Our primary objective here was to enhance watermelon cultivars (C. lanatus var. lanatus) with the exotic chloroplast and mitochondrial genomes of the desert watermelon $C$. colocynthis as has been shown in other important crop plants (Burke and Stewart, 2003; Stewart, 1990; Tao et al., 2004). Such breeding lines should be valuable in the development of cytoplasmic substitution lines, which have the nuclear genome of a watermelon cultivar but the cytoplasm of $C$. colocynthis versus that of cultivated watermelon (C. lanatus var. lanatus) and could be useful in examining if any nuclear-cytoplasmic gene interaction affects female flower production in watermelon.

The C. colocynthis exists in the hot deserts of North Africa, the Middle East, and South and Central Asia. As a desert plant, $C$. colocynthis can tolerate drought, intense sun exposure, and high day and low night temper- atures better than the cultivated watermelon (Althawadi and Grace, 1986; Schafferman et al., 1998). Notable differences exist between the chloroplast genome of $C$. lanatus var. lanatus and that of $C$. colocynthis (Dane and Lang, 2004). Introducing the chloroplast and mitochondrial genomes of $C$. colocynthis into watermelon cultivars may improve their ability to survive drought conditions. Maternal effect on drought tolerance has been indicated in other crop plants, including the pondweed Potamogeton anguillanus (Iida et al., 2007) or Moss Tortula ruralis (Oliver et al., 2010). Cytoplasmic substation lines containing the $C$. colocynthis cytoplasm versus that of cultivated watermelon should be useful for studying if the cytoplasm plays any role in drought tolerance.

\section{Origin}

USVL-220 was produced by first crossing a F1 hybrid [NHM (C. lanatus var. lanatus $) \times$ Griffin 14113 (C. lanatus var. citroides)] with C. colocynthis PI 386015 (used as the maternal parent). Then, most of the nuclear genes of this interspecific hybrid plant [PI 386015 $\times$ $(\mathrm{NHM} \times$ Griffin 14113)] were replaced with nuclear genes from three watermelon cultivars (including Allsweet, Extra Early Sugar Baby, and Charleston Gray) through a series of outcrosses in which these watermelon cultivars were used as the male (pollinator) parents (Fig. 1). An F1 plant derived from the final outcross, in which an 'Allsweet' plant was used as the male parent, was selfpollinated and an F2 plant was selected. This F2 plant, which had elongated oval fruits with green dappled rind (rind thickness of 0.7 to 0.8 inch), red flesh, and sweet flavor (soluble solid content of $8.5 \%$ to $11.0 \%$ ), was selected and self-pollinated. Progenies were selected using the same fruit quality criteria for eight successive generations to produce F10 seeds. These F10 seeds were designated as USVL-220 (Fig. 1).

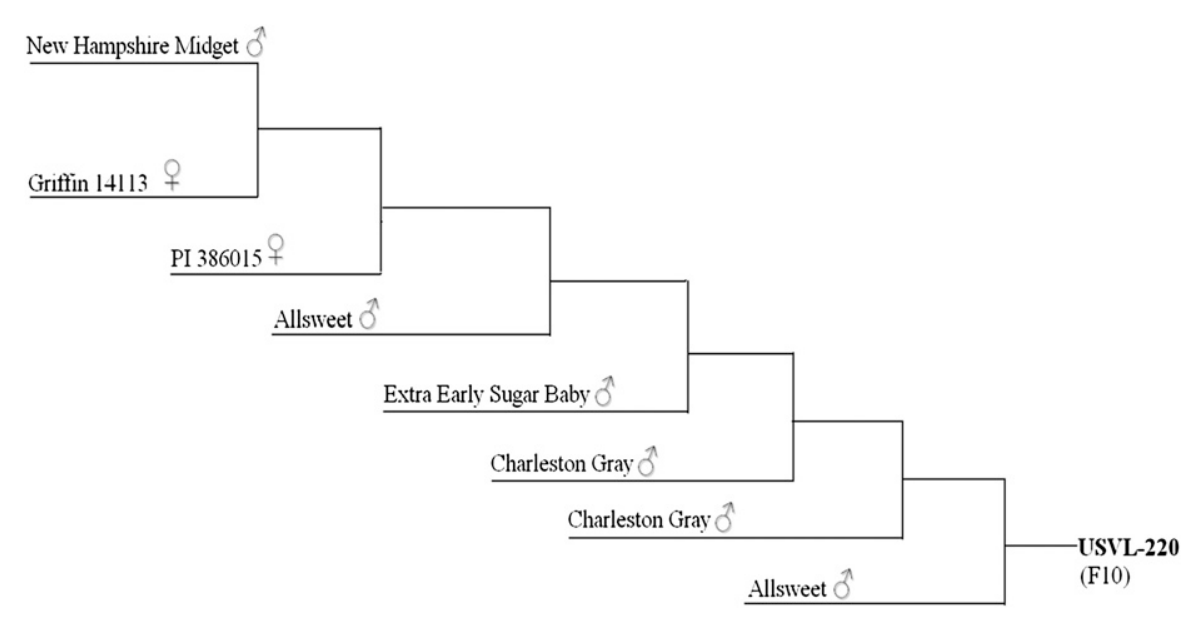

Fig. 1. Pedigree of USVL-220 showing the processes of replacing most of the nuclear genes of $C$. colocynthis with those of watermelon cultivars (Citrullus lanatus var. lanatus) while retaining the maternally inherited cytoplasmic background (chloroplast and mitochondrial genomes). 


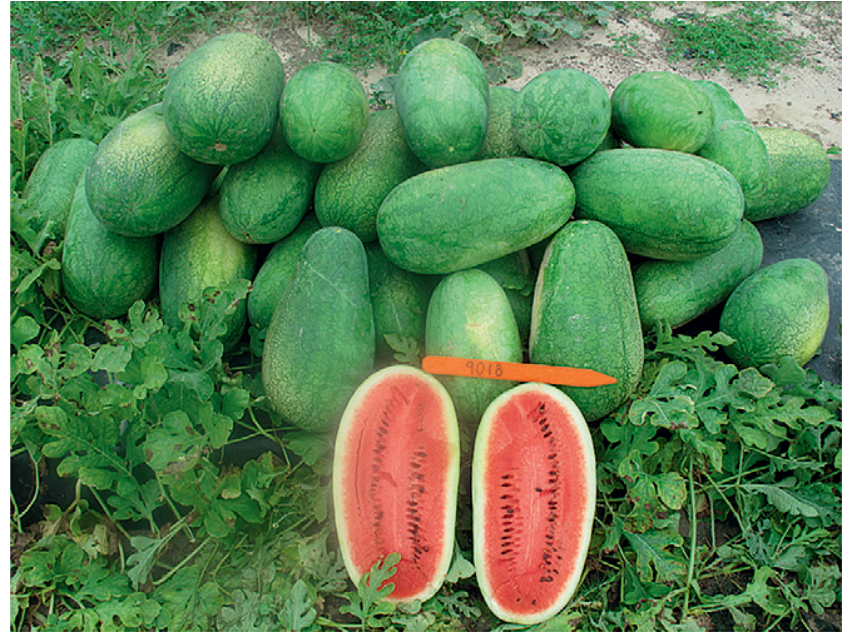

Fig. 2. USVL-220 fruit harvested in the field in Charleston, SC.

\section{Description}

USVL-220 plants produce elongated ovularshaped fruits with green dappled rind (rind thickness of 0.7 to 0.8 inch) and red flesh (Fig. 2). In field trials (complete randomized blocks with three entries and three plants with a 3-foot distance between them in each entry/plot) in Charleston, SC (summers of 2008 and 2009), USVL-220 plants produced (on average) 1.7 large mature fruits $(36.3 \mathrm{~cm}$ long and $18.5 \mathrm{~cm}$ wide and weighing $6.08 \mathrm{~kg}$ ) in mid-to-late season (76 to $78 \mathrm{~d}$ postplanting) and 1.1 smaller $(26.5 \mathrm{~cm}$ long and $13.8 \mathrm{~cm}$ width and an average weight of $4.35 \mathrm{~kg}$ ) fruit per plant that mature at 82 to $84 \mathrm{~d}$ post-planting. This yield was similar to that of 'Charleston Gray' and 'Jubilee' plants grown in the same field in Charleston, SC (2008 and 2009). The 'Charleston Gray'

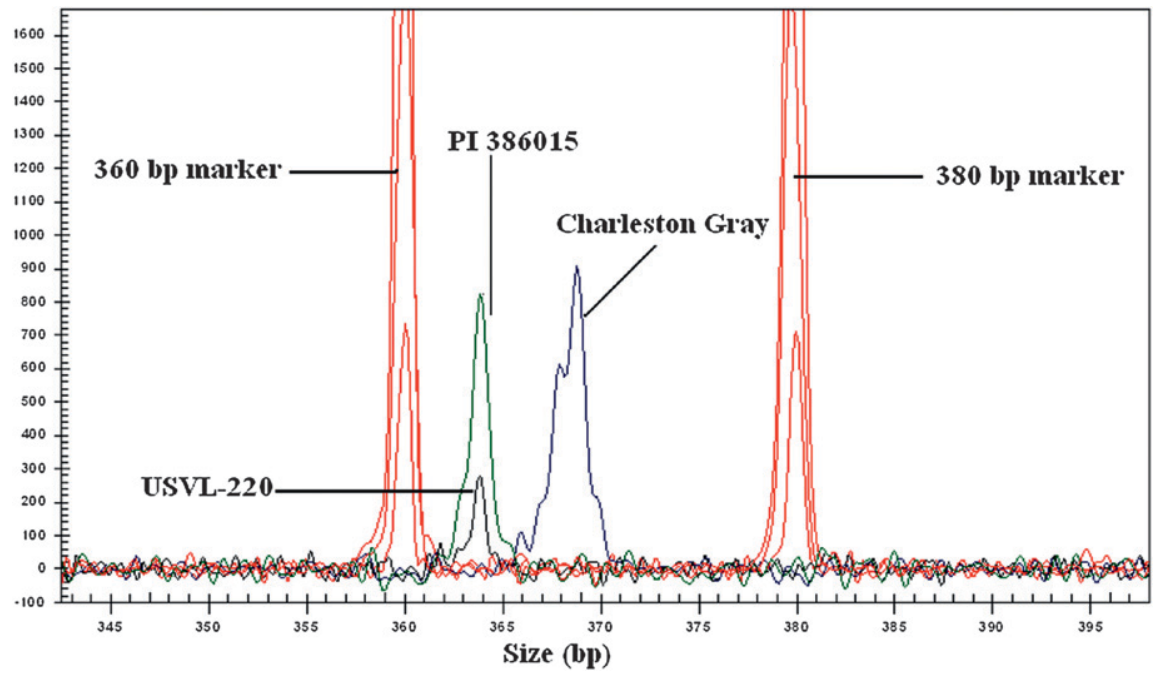

Fig. 3. Chloroplast DNA fragments of 'Charleston Gray' (368.8 bp) (Citrullus lanatus var. lanatus), Citrullus colocynthis PI 386015 (363.7 bp), and USVL-220 (363.7 bp) amplified by the chloroplast DNA primer pair Cucumis-Cp-4F (5' CCTTCTCTTCGGGATCG) and Cp-4R (5' GAGGTTAGAGACCGCTCA) in polymerase chain reaction (PCR) as described by Levi et al. (2009).

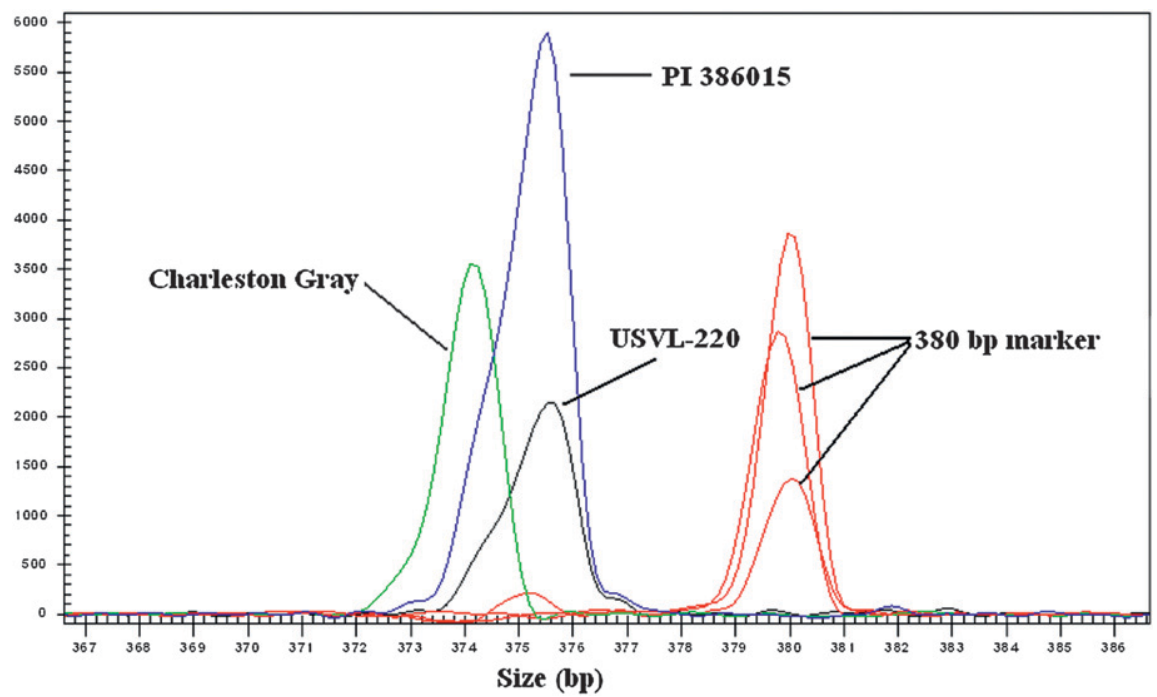

Fig. 4. Mitochondrial DNA fragments of 'Charleston Gray' (374 bp) (Citrullus lanatus var. lanatus), Citrullus colocynthis PI 386015 (375.8 bp), and USVL-220 ( $375.8 \mathrm{bp}$ ) amplified by the mitochondrial DNA primer pair 355-11F (5' CTATACTCCATACGGCCTTG) and 355-11R (5' GAACGAGAGAAGCTATCG $\mathrm{AG}$ ) in polymerase chain reaction (PCR), as described by Levi et al. (2009). 
plants had an average of 1.4 large mature fruits $(42.6 \mathrm{~cm}$ long and $20.1 \mathrm{~cm}$ wide and weighing $7.8 \mathrm{~kg})$ and 1.1 small fruits $(29.0 \mathrm{~cm}$ long and $17.7 \mathrm{~cm}$ width and an average weight of $4.62 \mathrm{~kg}$ ), whereas the 'Jubilee' plants produced an average of 1.6 large mature fruits $(39.1 \mathrm{~cm}$ long and $20.2 \mathrm{~cm}$ wide and weighing $7.08 \mathrm{~kg})$ and 1.2 smaller $(26.2 \mathrm{~cm}$ long and $14.6 \mathrm{~cm}$ width and an average weight of $4.34 \mathrm{~kg}$ ). Mature fruits of USVL-220 have red flesh color (Fig. 2) with an average soluble solid content of $8.5 \%$ to $11.0 \%$ [measured in the field for three different fruits in each of three random plots, using an Extech RF15 (0\% to $32 \%$ ) portable refractometer (Extech Instruments Corp., Waltham, MA)]. The fruits of USVL-220 have firm flesh with slightly crispy texture and did not exhibit any hollow heart in the fields in Charleston, SC (2008 to 2009). The fruits contain brown seeds (7.0 $\mathrm{mm}$ long and $4 \mathrm{~mm}$ width) (Fig. 2). Our greenhouse experiments indicated that USVL-220 is moderately susceptible to southern root-knot nematode (Meloidogyne incognita) with an average root gall index of 4.1 (similar to 'Crimson Sweet', which had gall index of 4.3 , but better than the $C$. colocynthis PI 386015 which had gall index of 5.0) on a scale of 1.0 to 5.0 , in which $1.0=$ no galls and $5.0=$ greater than $80 \%$ of root system galled (as has been described by Thies and Levi, 2003, 2007).

In a previous study (Levi et al., 2006), we released three breeding lines, including USVL200 (early, globular fruits with dark green rind and yellow-pink flesh), USVL-205 (early, globular fruits with dark green rind and red flesh), and USVL-210 (elongated fruit with light green-gray rind and pink-red flesh), which also contain the chloroplast and mitochondrial genomic background of C. colocynthis (Levi and Thomas, 2005). Similar to USVL210, here USVL-220 also produces elongated fruits (Fig. 2). However, the fruits of USVL220 are smaller $(36 \mathrm{~cm}$ long and $18.4 \mathrm{~cm}$ wide and weighing $5.80 \mathrm{~kg}$ ) and slightly more ovular than those of USVL-210 $(42 \mathrm{~cm}$ long and $18 \mathrm{~cm}$ wide and weighing $6.49 \mathrm{~kg}$ ). The USVL-220 fruits have green dappled rind with red flesh (Fig. 2), whereas the USVL-210 fruits have a light green-gray rind and pinkred flesh color (Levi et al., 2006). The nuclear genome of USVL-210 contains mostly genes of the cultivar Charleston Gray (Levi et al., 2006), whereas USVL-220 also contains genes from 'Sugar Baby' and 'Allsweet' (Fig. 2). As indicated, the possibility of interaction between nuclear and cytoplasmic (mitochondria or chloroplast) genes in controlling flower production may not be excluded and may have an effect on female flowers production in the breeding lines containing cytoplasmic background derived from C. colocynthis, including USVL-200 or USVL-205 (one female flower for every five to seven male flowers), and USVL-210 (one female flower for every seven to 10 male flowers) versus USVL-220 (one female flower for every seven to eight male flowers). Further studies using cytoplasmic substitution lines that contain the nuclear genome of these breeding lines (USVL-200,
USVL-205, USVL-210, and USVL 220) and the cytoplasm of $C$. colocynthis versus that of cultivated watermelon (C. lanatus var. lanatus) are needed to prove this assumption.

Polymerase chain reaction (PCR) analysis using chloroplast and mitochondrial DNA primers was performed, as described for expressed sequence tag primers by Levi et al. (2009), to determine if USVL-220 contains chloroplast and mitochondrial genomes of $C$. colocynthis (PI 386015). In the PCR analysis, we used eight chloroplast DNA primer pairs derived from cucumber (Cucumis sativus L.) chloroplast genome (Plader et al., 2007) and 10 mitochondrial DNA primer pairs derived from watermelon (Citrullus lanatus) mitochondrial genome (Alverson et al., 2010) (primer pair sequences are not shown). As expected from our primer design-based and sequence data, each of these primer pairs produced chloroplast or mitochondrial DNA fragments in the size range of 300 to $380 \mathrm{bp}$ (data are not shown). However, only one of each of the eight chloroplast primer pairs and one of each of the 10 mitochondrial primer pairs produced polymorphic fragments between C. colocynthis (PI 386015) and C. lanatus var. lanatus ('Charleston Gray') (as shown in Figs. 3 and 4). These primer pairs confirmed that the USVL-220 plants retain chloroplast (Fig. 3) and mitochondrial (Fig. 4) genomes derived from the maternal C. colocynthis parent (PI 386015). Restriction fragment length polymorphism and PCR analysis data of plants that were successively used as the maternal parents in early generations $(\mathrm{F} 1, \mathrm{BC} 1$, and $\mathrm{BC} 2)$ confirmed that they contained increasing amounts of the nuclear genome of watermelon cultivars $(C$. lanatus var. lanatus) and chloroplast and mitochondrial genomes derived from $C$. colocynthis (as indicated by Levi and Thomas, 2005).

USVL-220 may be useful for scientists and plant breeders interested in enhancing watermelon cultivars with cytoplasm (chloroplast and mitochondrial genomes) of wild watermelon species. This breeding line may be used for examining the effect of the desert species $C$. colocynthis cytoplasm on photosynthesis and respiration. In breeding programs, USVL-220 should be used as the maternal parent to retain the $C$. colocynthis cytoplasm.

\section{Seed Availability}

Small samples of seed of USVL-220 are available for distribution to interested research personnel and plant breeders who should make a written request to Dr. Amnon Levi, U.S. Vegetable Laboratory, 2700 Savannah Highway, Charleston, SC 29414-5334. Seed of USVL-220 also will be submitted to the National Plant Germplasm System where they will be available for research purposes, including the development and commercialization of new cultivars. It is requested that appropriate acknowledgment of the source be given when this germplasm contributes to research or development of a new breeding line or cultivar.

\section{Literature Cited}

Althawadi, A.M. and J. Grace. 1986. Water use by the desert cucurbit Citrullus colocynthis (L.) Schrad. Oecologia 70:475-480.

Alverson, A.J., X. Wei, D.W. Rice, D.B. Stern, K. Barry, and J.D. Palmer. 2010. Insights into the evolution of mitochondrial genome size from complete sequences of Citrullus lanatus and Cucurbita pepo (Cucurbitaceae). Mol. Biol. Evol. 27:1436-1448.

Burke, T. and J.McD. Stewart. 2003. Development of molecular markers to distinguish cytoplasm substitution lines of cotton. Summaries of Arkansas Cotton Research. AAES Research Series 521:23-28.

Dane, F. and P. Lang. 2004. Sequence variation at cpDNA regions of watermelon and related species: Implications for the evolution of Citrullus haplotypes. Amer. J. Bot. 91:1922-1929.

Diolez, P., J. Davy De Virville, A. Latché, F. Moreau, J.C. Pech, and M. Reid. 1986. Role of the mitochondria in the conversion of 1aminocyclopropane 1-carboxylic acid to ethylene in plant tissues. Plant Sci. 43:13-17.

Ehlers, B.K., S. Maurice, and T. Bataillon. 2005. Sex inheritance in gynodioecious species: A polygenic view. Proc. Biol. Sci. 272:1795-1802.

Havey, M.J., J.D. McCreight, B. Rhodes, and G. Taurick. 1998. Differential transmission of the Cucumis organellar genomes. Theor. Appl. Genet. 97:122-128.

Iida, S., A. Yamada, M. Amano, J. Ishii, Y. Kadono, and K. Kosuge. 2007. Inherited maternal effects on the drought tolerance of a natural hybrid aquatic plant, Potamogeton anguillanus. J. Plant Res. 120:473-481.

Kheyr-Pour, A. 1980. Nucleo-cytoplasmic polymorphism for male sterility in Origanum vulgare L. J. Hered. 71:253-260.

Levi, A. and C.E. Thomas. 2005. Polymorphisms among chloroplast and mitochondrial genomes of Citrullus species and subspecies. Genet. Resources Crop Evol. 52:609-617.

Levi, A., C.E. Thomas, J.A. Thies, A.M. Simmons, K. Ling, and H.F. Harrison. 2006. Novel watermelon breeding lines containing chloroplast and mitochondrial genomes of the desert species citrullus colocynthis. HortScience 41:463-464.

Levi, A., C.E. Thomas, T.C. Wehner, and X. Zhang. 2001. Low genetic diversity indicates the need to broaden the genetic base of cultivated watermelon. HortScience 36:1096-1101.

Levi, A., W.P. Wechter, and A.R. Davis. 2009 EST-PCR markers representing watermelon fruit genes are polymorphic among watermelon heirloom cultivars sharing a narrow genetic base. Plant Genetic Resources. 7:16-32.

Oliver, M.J., A.G. Murdock, B.D. Mishler, J.V. Kuehl, J.L. Boore, D.F. Mandoli, K.D. Everett, P.G. Wolf, A.M. Duffy, and K.G. Karol. 2010 Chloroplast genome sequence of the moss Tortula ruralis: Gene content and structural arrangement relative to other green plant chloroplast genomes. Biomed Central (BMC) Genomics 11:143.

Plader, W., Y. Yukawa, M. Sugiura, and S. Malepszy. 2007. The complete structure of the cucumber (Cucumis sativus L.) chloroplast genome: Its composition and comparative analysis. Cell. Mol. Biol. Lett. 12:584-594.

Ross, M.D. 1978. The evolution of gynodioecy and subdioecy. Evolution 32:174-188.

Ross, M.D. and H.R. Gregourius. 1985. Selection with gene-cytoplasm interactions. II. Maintenance of gynodioecy. Genetics 109:427-439.

Salman, A., A. Levi, S. Wolf, and T. Trebitsh. 2008. ACC synthase genes are polymorphic in watermelon (citrullus spp.) and differentially 
expressed in flowers and in response to auxin and gibberellin. Plant Cell Physiol. 49:740-750.

Schafferman, D., A. Beharav, E. Shabelsky, and Z. Yaniv. 1998. Evaluation of Citrullus colocynthis, a desert plant native in Israel, as a potential source of edible oil. J. Arid Environ. 40:431-439.

Stewart, J.M. 1990. New cytoplasms for cotton, p. 55-58. In: Oosterhuis, D.M. (ed.). Proc. 1990 Cotton Research Meeting. Ark. Agr. Exp. Sta. Special Report 144.
Tao, D., F. Hu, J. Yang, G. Yang, Y. Yang, P. Xx, J. Li, C. Ye, and L. Dai. 2004. Cytoplasm and cytoplasm-nucleus interactions affect agronomic traits in japonica rice. Euphytica 135: 129-134.

Thies, J.A. and A. Levi. 2003. Resistance of watermelon germplasm to peanut root-knot nematode. HortScience 38:1417-1421.

Thies, J.A. and A. Levi. 2007. Characterization of watermelon (Citrullus lanatus var. citroides) germplasm for resistance to root-knot nematodes. HortScience 42:1530-1533.

Van der Hulst, R.G.M., P. Meirmans, P.H. van Tienderen, and J.M.M. van Damme. 2004. Nuclear-cytoplasmic male-sterility in diploid dandelions. Heredity 93:43-50.

Wade, M.J. and D.E. McCauley. 2005. Paternal leakage sustains the cytoplasmic polymorphism underlying gynodioecy but remains invisible by nuclear restorers. Amer. Nat. 166:592-602. 